RODRIGUES, M. T.; RAMOS, E. W. V. B.; BUSO; W. H. D. Irrigated common beans submitted to different doses and periods of manganese application Revista de Agricultura Neotropical, Cassilândia-MS, v. 8, n. 4, e6018, out./dez. 2021. ISSN 2358-6303. DOI: https://doi.org/10.32404/rean.v8i4.6018..

\title{
Irrigated common beans submitted to different doses and periods of manganese application
}

\author{
Mateus Gonçalves Rodrigues ${ }^{1}$, Eliene Wellita Vieira Barcelos Ramos ${ }^{1}$, Wilian Henrique Diniz \\ Buso $^{1}$ \\ ${ }^{1}$ Instituto Federal Goiano, Campus Ceres, Ceres, Goiás, Brasil. E-mail: mateuspgtu@ hotmail.com, wilian.buso@ifgoiano.edu.br, \\ elienewellita@hotmail.com
}

Received: 26/03/2021; Accepted: 18/08/2021.

\section{ABSTRACT}

Brazil is the largest beans producer, and this legume is one of the primary sources of plant-based proteins. Some minerals, such as manganese, are essential for this crop development. From the socio-economic importance of the beans crop, this study aims to evaluate the agronomic performance of irrigated common beans grown under different doses of manganese on two application periods. The experiment was conducted in the experimental area of the Instituto Federal Goiano, Campus Ceres (GO), adopting an experimental design arranged in a 2x4 factorial scheme with four replications, comprising two periods of application (V4 and R5 phenological stages) and four Mn doses $\left(0,150,300,450 \mathrm{~g} \mathrm{ha}^{-1}\right)$. The variables evaluated were plant height $(\mathrm{m})$, number of pods per plant (NPP), number of grains per pod, 1000-grain weight $(\mathrm{g})$, and yield $\left(\mathrm{kg} \mathrm{ha}^{-1}\right)$. The dose of $450 \mathrm{~g} \mathrm{ha}^{-1}$ of Mn provided the highest yield regardless of the application period. The higher NPP was obtained with the dose of $150 \mathrm{~g} \mathrm{ha}^{-1}$ in V4. Also, the dose of $450 \mathrm{~g} \mathrm{ha}^{-1}$ of Mn in V4 provided the most significant 1000-grain weight.

Keywords: Fertilization. Agronomic Parameters. Grain Yield

\section{Feijoeiro comum irrigado submetido á diferentes doses de manganês e épocas de aplicação}

\section{RESUMO}

O Brasil é o maior produtor de feijão e esta leguminosa é uma das maiores fontes de proteínas vegetais. Alguns minerais, como o manganês, são extremamente importantes para o desenvolvimento desta cultura. Sabendo da importância socioeconômica da cultura do feijoeiro, objetivou-se avaliar o desempenho agronômico do feijoeiro comum irrigado, cultivado sob diferentes doses de manganês e duas épocas de aplicação. O experimento foi conduzido na área experimental do Instituto Federal Goiano, Campus Ceres (GO), adotando delineamento experimental em esquema fatorial $2 \times 4$ com quatro repetições, sendo dois períodos de aplicação (V4 e R5) e quatro doses de $\mathrm{Mn}\left(0,150,300,450 \mathrm{~g} \mathrm{ha}^{-1}\right)$. As variáveis analisadas foram: altura das plantas $(\mathrm{m})$, número de vagens por planta (NVP), número de grãos por vagem, massa de mil grãos $(\mathrm{g})$ e produtividade $\left(\mathrm{kg} \mathrm{ha}^{-1}\right)$. A dose de $450 \mathrm{~g}^{-1}$ de Mn proporcionou maior produtividade independente da época de aplicação. O maior NVP foi obtido com a dose de $150 \mathrm{~g} \mathrm{ha}^{-1}$, em V4. Também em V4, a dose de $450 \mathrm{~g} \mathrm{ha}^{-1}$ de Mn proporcionou maior peso de mil grãos.

Palavras-chave: Adubação. Parâmetros Agronômicos. Produtividade.. 


\section{Introduction}

Brazil is the world's largest common beans producer (Phaseolus vulgaris), and $50 \%$ of the national production is in Paraná, Minas Gerais, and Bahia (EMBRAPA, 2020). Concerning legumes in general, Brazil is the thirdlargest producer, after India and Myanmar (CONAB, 2019). According to CONAB (2019), the harvest 2019/2020 had approximately 2.89 million hectares, and the most grown crops were of color beans (44.77\%), followed by cowpeas $(44.11 \%)$ and black beans (11.12\%). CONAB (2020) indicates a projection of 3.2 million tons of beans in the 2020/2021 harvest.

Beans and other legumes are the most common sources of plant-based proteins, essential for human nutrition (Slywitch, 2012). The common bean is also considered a nutrient-demanding legume since its short cycle requires nutrients must be readily available at the appropriate time and place, providing better development of morphoagronomic traits of beans (Nascente et al., 2012; Lacerda et al., 2020).

Manganese $(\mathrm{Mn})$ and zinc $(\mathrm{Zn})$ are micronutrients and cofactors of several enzymatic activities, actuating as catalysts of reactions and presenting structural and regulatory functions (Bueno and Czepielewski, 2007). Marschner (2011) states that Mn is essential to plant respiration and nitrogen metabolism.

Beans have very defined phenological stages of development, ranging from V0 to V4 (vegetative stages of the plant) and from R5 to R9 (reproductive stages). In $\mathrm{V} 4$, the third trifoliate leaf opens, and this stage ends when flower buds appear. In R5, secondary branches develop, and the first flower buds appear, ending when flowering begins (Oliveira et al., 2018). The deficit of manganese in bean crops can result in chlorosis between the veins, associated with the development of small necrotic spots (Taiz and Zeiger, 2013).

From the importance of manganese for the development of bean crops and their socio-economic role in Brazil, this study aims to evaluate the agronomic performance of irrigated common beans grown with different doses of manganese in two periods of application.

\section{Material and Methods}

The experiment was conducted in the experimental area of the Instituto Federal Goiano, Campus Ceres (GO), at the coordinates $15^{\circ} 21^{\prime} 00^{\prime \prime} \mathrm{S}$ and $49^{\circ} 35^{\prime} 57^{\prime \prime} \mathrm{W}$ and altitude of $564 \mathrm{~m}$, under irrigation with a center pivot. The chemical analysis and soil granulometry for the layer between 0-20 cm are presented in Table 1 .

The experimental design was arranged in a $2 \times 4$ factorial scheme with four repetitions: two application periods (in the phenological stages V4 - third composite leaf open - and R5 - pre-flowering) and four Mn doses $\left(0,150,300,450 \mathrm{~g} \mathrm{ha}^{-1}\right)$. Before setting up the field experiment, the soil preparation was carried out. Initially, we performed heavy harrowing and ground leveling one day before sowing.

Fertilization was done in the bottom of the sowing furrow with $16 \mathrm{~kg} \mathrm{ha}^{-1}$ of $\mathrm{N}, 120 \mathrm{~kg} \mathrm{ha}^{-1}$ of $\mathrm{P}_{2} \mathrm{O}_{5}$, and 40 $\mathrm{kg} \mathrm{ha}{ }^{-1}$ of $\mathrm{K}_{2} \mathrm{O}$. The sowing was carried out on $05 / 14 / 2019$, adopting a spacing of $0.50 \mathrm{~m}$ between the rows, distributing 12 seeds per meter to obtain a final population of 200 thousand plants $\mathrm{ha}^{-1}$. Seeds were treated with Pyrclostrobin (Satandak Top ${ }^{\circledR}$ ) in the dose of $200 \mathrm{ml}$ of the product per $100 \mathrm{~kg}$ of seeds.

Foliar application of $\mathrm{Mn}$ was performed at the phenological stages V4 (06/07/2019) and R5 $(06 / 17 / 2019)$. The foliar mineral fertilizer used was MAN $144^{\circledR}$ with $14 \%$ of manganese $\left(189.00 \mathrm{~g} \mathrm{~L}^{-1}\right)$. One day after sowing, the weed control was carried out using the pre-emergent herbicide S-Metolacloro (Dual Gold ${ }^{\circledR}$ ) $\left(1.0 \mathrm{~L} \mathrm{ha}^{-1}\right)$. In post-emergence, the herbicides Bentazona $\left(\right.$ Amplo ${ }^{\circledR}$ ) and Cletodim $\left(\right.$ Select ${ }^{\circledR}$ ) were applied, with dosages of $0.8 \mathrm{~L} \mathrm{ha}^{-1}$ and $0.5 \mathrm{~L} \mathrm{ha}^{-1}$, respectively.

The control of pests and diseases followed the technical recommendations for common beans crops. The interval of irrigation was two days. The irrigation management was carried out using a pan-evaporation, estimating the irrigation depth based on the $\mathrm{Kc}$ of the crop according to their phenological stages. Each experimental unit was composed of four rows 5.0 meters in length. Borders of $50 \mathrm{~cm}$ were discarded for the evaluations. The harvest was carried out on 08/24/2019.

Table 1. Result of chemical analysis and soil particle size in the $0-20 \mathrm{~cm}$ soil layer before the experiment installation

\begin{tabular}{|c|c|c|c|c|c|c|c|}
\hline \multirow[t]{2}{*}{ Sand } & Silt & Clay & \multirow{2}{*}{$\mathrm{pH}$ in $\mathrm{H}_{2} \mathrm{O}$} & $\mathrm{OM}$ & $\mathrm{Ca}$ & $\mathrm{Mg}$ & $\mathrm{Al}$ \\
\hline & $\mathrm{g} \mathrm{kg}^{-1}$ & & & $\overline{\mathrm{g} \mathrm{dm}^{-}}$ & \multicolumn{3}{|c|}{$\mathrm{cmol} \mathrm{dm}^{-3}$} \\
\hline \multirow[t]{4}{*}{482} & 400 & 478 & 5.82 & 22 & 3.85 & 1.94 & 0.00 \\
\hline & $\mathrm{H}+\mathrm{AL}$ & $\mathrm{K}$ & $\overline{\mathrm{CEC}}$ & $\mathrm{K}$ & $\bar{P}$ & \multirow{2}{*}{ BS } & \\
\hline & $\mathrm{cmold}$ & & & $\mathrm{mg} \mathrm{d}_{1}$ & & & \\
\hline & 3.80 & 0.56 & 10.15 & 180.0 & 30.00 & \multicolumn{2}{|c|}{$62.57 \%$} \\
\hline
\end{tabular}

OM - Organic matter; CEC - Cation exchange capacity; SB - Base saturation 
The plants were manually plucked. Posteriorly, all plants in the central rows (16/08/2020) were threshed with a bean thresher. The samples were weighed on a precision scale to determine the grain yield, correcting the grain moisture to $13 \%$. The plant height $(\mathrm{m})$, number of pods per plant, number of grains per pod, 1000-grain weight $(\mathrm{g})$, and grain yield (kg ha-1) were evaluated. The data from the yield components and the agronomic traits were submitted to the analysis of variance. The means were compared by the Tukey test at $5 \%$ probability. Also, regression equations were adjusted according to the doses of the nutrient, using the software R.

\section{Results and Discussion}

There was no significant interaction $(\mathrm{P}>0.05)$ for plant height $(\mathrm{PH})$, number of grains per pod (NGP), and grain yield (Y). Then, the factors were analyzed individually. The interaction between the period of application and the doses was significant only for the number of grains per pod (NGP) and 1000-grain weight (GW), according to Table 2. The different doses of manganese and the application periods did not influence plant height, regardless of the treatment used (Table 3). Mota et al. (2018), while evaluating different doses of manganese fertilizers in cowpeas (Vigna unguiculata), observed that a quadratic regression curve fit the parameter plant height $(\mathrm{PH})$. This result differs from our study, in which no regression equation is adjusted to the data obtained. However, those authors affirmed that the control treatment $\left(0 \mathrm{~g} \mathrm{ha}^{-1}\right)$ and the highest dose $\left(400 \mathrm{~g} \mathrm{ha}^{-1}\right)$ provided higher plant heights.

Two types of stress may cause this fact. The first type of stress is caused by manganese deficiency, making the plant stimulates its growth, both in its shoot and roots, to absorb more nutrients and supply this deficit. The second stress is caused by the excess of manganese, in which the manganese toxicity makes the plant grow faster to reach more quickly the reproductive stage (Mota et al., 2018). The number of grains per pod (NGP) did not present a significant difference regarding the manganese application periods (Table 3).

There was a significant interaction between doses and periods of application for the number of pods per plant (NPP) (Table 4). It was observed that the number of pods produced by the plant without manganese application was statistically equal in the two periods (V4: 9.69, and R5: 10.72) (Table 4). The dose of $150 \mathrm{~g}$ of manganese provided the highest number of pods per plant (NPP) when applied in the vegetative stage V4 (15.83 pods). Regardless of the application period, the doses of 300 and $400 \mathrm{~g}$ ha-1 did not present a significant difference concerning NPP (Table 4).

Table 2. Analysis of variance of plant height (PH), number of pods per plant (NPP), number of grains per pod (NGP), 1000-grain weight $(\mathrm{GW})$, and grain yield $(\mathrm{Y})$ of common beans plants submitted to different doses and application periods of manganese and the interaction Period x Dose (P x D).

\begin{tabular}{lllllll}
\hline \multirow{2}{*}{ SV } & \multicolumn{7}{l}{ Mean square } & & \\
\cline { 2 - 6 } & DF & PH & NPP & NGP & GW & Y \\
\hline Period & 1 & $0.0226^{\text {ns }}$ & $4.8828^{* *}$ & $0.0165^{\text {ns }}$ & $4105.184^{\text {ns }}$ & $1125000.00^{* *}$ \\
Doses & 3 & $0.0281^{\text {ns }}$ & $13.3948^{* *}$ & $0.3701^{\text {ns }}$ & $29013.805^{* *}$ & $1063333.30^{* *}$ \\
P x D & 3 & $0.0229^{\text {ns }}$ & $16.5272^{* *}$ & $0.1342^{\text {ns }}$ & $21072.641^{*}$ & $168333.30^{\text {ns }}$ \\
\hline CV\% & & 14.96 & 6.12 & 12.87 & 18.70 & 11.12 \\
\hline
\end{tabular}

** Significant at $1 \%$ probability and ns not significant by the F-test at 5\% probability. Period (application period of manganese); Doses (applied doses); Period x Doses (interaction between the factors period and doses); CV\% (coefficient of variation); SV (source of variation); DF (degrees of freedom).

Table 3. Means from plant height (PH), number of pods per plant (NPP), and grain yield (Y) of irrigated common beans crop grown under different manganese doses and application periods

\begin{tabular}{llll}
\hline \multirow{2}{*}{ Stage } & \multicolumn{2}{l}{ Agronomic Traits } & GY $\left(\mathrm{kg} \mathrm{ha}^{-1}\right)$ \\
\cline { 2 - 4 } & PH $(\mathrm{m})$ & NPP & $2887.5 \mathrm{~b}$ \\
\hline V4 & $1.28 \mathrm{a}$ & $4.96 \mathrm{a}$ & $3262.5 \mathrm{a}$ \\
\hline R5 & $1.22 \mathrm{a}$ & $5.00 \mathrm{a}$ & $\mathrm{GY}\left(\mathrm{kg} \mathrm{ha}^{-1}\right)$ \\
\hline 0 & $\mathrm{PH}(\mathrm{m})$ & NPP & $2625.00 \mathrm{c}$ \\
150 & $1.29 \mathrm{a}$ & $4.83 \mathrm{a}$ & $3175.00 \mathrm{ab}$ \\
300 & $1.19 \mathrm{a}$ & $4.78 \mathrm{a}$ & $3000.00 \mathrm{bc}$ \\
450 & $1.22 \mathrm{a}$ & $5.09 \mathrm{a}$ & $3500.00 \mathrm{a}$
\end{tabular}

Means followed by the same lowercase letters in the column are statistically equal according to the Tukey test at 5\% probability. V4 (application of manganese in the vegetative stage V4); R5 (application of manganese in the reproductive stage R5). 0 (no manganese application); 150 (application of 150 g.ha-1 of manganese); 300 (application of 300 g.ha-1 of manganese); 450 (application of 450 g.ha-1 of manganese). 
Table 4. Interactions between the application period and the manganese doses on the number of pods per plant (NPP) of irrigated common beans crop

\begin{tabular}{lcccc}
\hline \multirow{2}{*}{ Stage } & \multicolumn{4}{c}{ Doses $\left(\mathrm{g} \mathrm{ha}^{-1}\right)$} \\
\cline { 2 - 5 } & 0 & 150 & 300 & 450 \\
\hline V4 & $9.69 \mathrm{aC}$ & $15.83 \mathrm{aA}$ & $10.80 \mathrm{aBC}$ & $11.62 \mathrm{aB}$ \\
R5 & $10.72 \mathrm{aA}$ & $10.77 \mathrm{bA}$ & $11.58 \mathrm{aA}$ & $11.74 \mathrm{aA}$
\end{tabular}

Means followed by the same lowercase letter in the column and uppercase in the line are statistically equal according to the Tukey test at 5\% probability. V4 (application of manganese in the vegetative stage V4); R5 (application of manganese in the reproductive stage R5). 0 (no manganese application); 150 (application of 150 g.ha ${ }^{-1}$ of manganese); 300 (application of 300 g.ha $^{-1}$ of manganese); 450 (application of $450 \mathrm{~g} \cdot \mathrm{ha}^{-1}$ of manganese).

In this study, the application of $150\left(\mathrm{~g} \mathrm{ha}^{-1}\right)$ in V4 provided a higher NPP than the application in R5. The application in V4 promoted increments of $31.96 \%$ in NPP compared with R5, according to Table 4. A study by Fernandes et al. (2007) with foliar application of $\mathrm{Mn}$ in common beans $\left(0,150,300\right.$, and $\left.600 \mathrm{~g} \mathrm{ha}^{-1}\right)$ observed that the NPP increased up to the dose of 258 ( $\mathrm{g} \mathrm{ha}^{-1}$ ), whose value was 15.97 pods per plant. According to the description of these authors, higher amounts of Mn can reduce the NPP, which indicates that high doses of Mn have a phytotoxic effect on plants. The same effect may have occurred in this study with the application of Mn in R5 in the dose of $150\left(\mathrm{~g} \mathrm{ha}^{-1}\right)$.

The phenological stage V4, individually evaluated, presented better adjustment to the quadratic model. The dose of $250 \mathrm{~g} \mathrm{ha}^{-1}$ of manganese provided plants with the highest NPP, with 14.29 pods per plant (Figure 1). Concerning stage R5, a better adjustment to the quadratic model was observed, according to Figure 1. Fernandes et al. (2007) observed a quadratic effect of NPP due to the foliar application of Mn regardless of the application period (R5 and R6)

The 1000-grain weight (WG) was influenced by the interactions between the applied doses and the phenological stages (Table 2). The plants without manganese applications $\left(0 \mathrm{~g} \mathrm{ha}^{-1}\right)$ presented equal WG (V4: $236.52 \mathrm{~g}$ and R5: $313.26 \mathrm{~g}$ ) (Table 5). The same was observed for WG in plants fertilized with 50 and $300 \mathrm{~g} \mathrm{ha}^{-1}$ of $\mathrm{Mn}$. In the dose of $450 \mathrm{~g} \mathrm{ha}^{-1}$, the highest WG was observed in plants that received the manganese application in the vegetative stage V4 (491.8448 g) (Table 5). Oliveira et al. (2015) found values of $282.6 \mathrm{~g}$ with $\mathrm{Mn}$ application in $\mathrm{V} 4$, with a dose of $62.5 \mathrm{~g} \mathrm{ha}^{-1}$. The dose used by the authors indicates that $\mathrm{Mn}$ application in V4 can lead to increments in grain weight, which is also observed in this study, in which the dose of $150 \mathrm{~g} \mathrm{ha}^{-1}$ obtained $27 \%$ more grain mass than the zero dose (Table 5)

The model of linear regression was significant $(\mathrm{P}<0.01)$ for 1000 -grain weight in stage $\mathrm{V} 4$, and the quadratic model was significant for stage R5 (Figure 2). During stage V4, the 1000-grain weight tends to increase as dosages increase. However, during the preflowering (R5), this behavior did not occur. With doses superior to $333.33 \mathrm{~g} \mathrm{ha}^{-1}$, the grain weight tends to decrease (Figure 2). The maximum response point was $410.2 \mathrm{~g}$ in R5 (Figure 2).

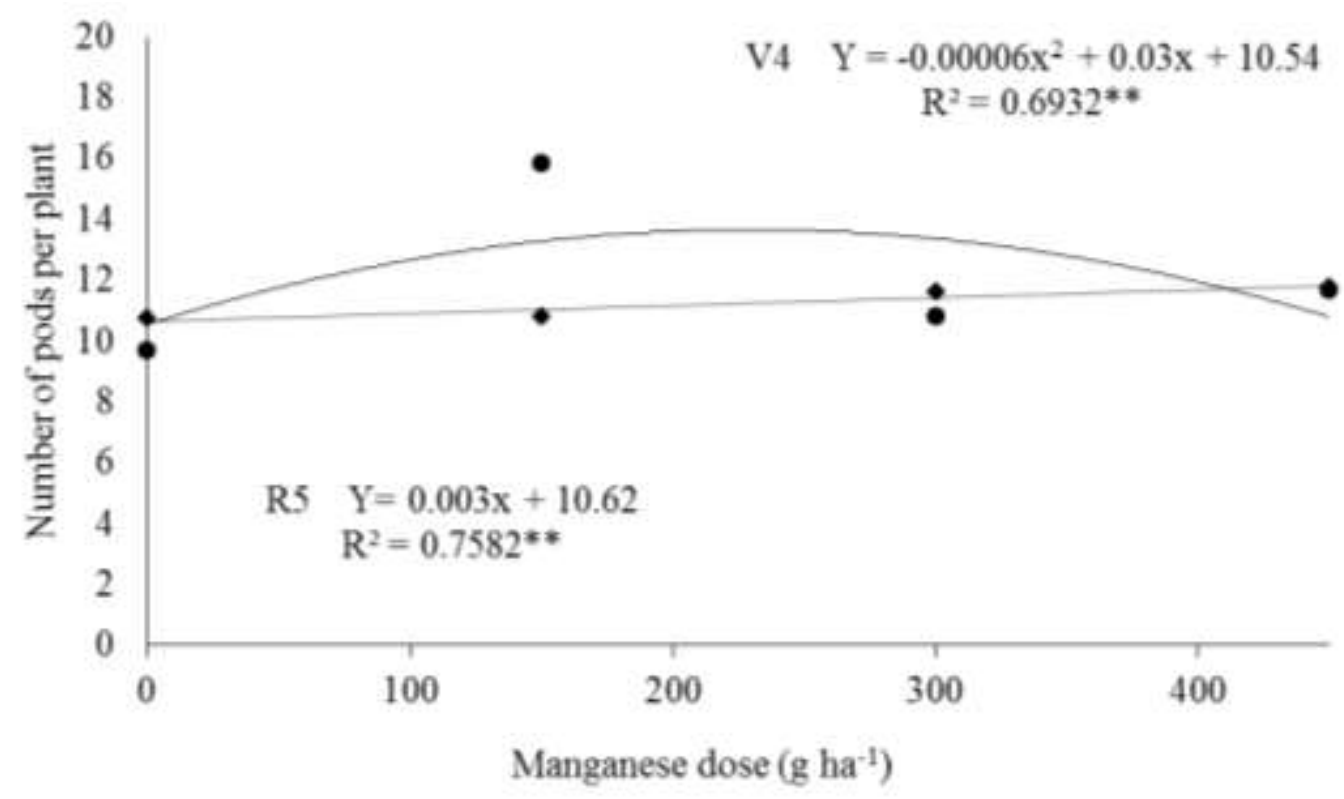

Figure 1. Number of pods per plant (NPP) according to the manganese doses application on two periods in an irrigated common beans crop. 
Table 5. Interaction between application period and manganese dose on the 1000 -grain weight (WG) $\left(\mathrm{g} \mathrm{ha}^{-1}\right)$ of irrigated common beans crop

\begin{tabular}{lcccc}
\hline \multirow{2}{*}{ Stage } & \multicolumn{4}{c}{ Doses $\left(\mathrm{g} \mathrm{ha}^{-1}\right)$} \\
\cline { 2 - 5 } & 0 & 150 & 300 & 450 \\
\hline V4 & $236.52 \mathrm{aC}$ & $326.65 \mathrm{aBC}$ & $402.03 \mathrm{aAB}$ & $491.84 \mathrm{aA}$ \\
R5 & $313.26 \mathrm{aA}$ & $349.30 \mathrm{aA}$ & $374.87 \mathrm{aA}$ & $328.98 \mathrm{bA}$
\end{tabular}

Means followed by the same lowercase letters in the column and uppercase in the lines are statistically equal according to the Tukey test at 5\% significance. V4 (application of manganese in the vegetative stage V4); R5 (application of manganese in the reproductive stage R5). 0 (no application of manganese); 150 (application of $150{\mathrm{~g} . h a^{-1}}^{-1}$ of manganese); 300 (application of 300 g.ha ${ }^{-1}$ of manganese); 450 (application of 450 g.ha ${ }^{-1}$ of manganese).
The grain yield was influenced by different periods of manganese application (Table 3). Fertilizing in stage R5 provided a higher yield with $3,262.5 \mathrm{~kg} \mathrm{ha}^{-1}$ (Table 3). However, the maximum recommended dose for this nutrient was the one that provided the highest yield once the superior doses resulted in an increasing reduction in soybean yield.

The manganese doses provided different yields and presented better adjustment to the linear model (Figure $3)$. The control ( $0 \mathrm{~g} \mathrm{ha}^{-1}$ of manganese) resulted in $2,625.00 \mathrm{~kg} \mathrm{~h}^{-1}$, which is statistically inferior to the doses of 150,300 , and $450 \mathrm{~g}$ of manganese, with yields of $3,175,3,000$, and 3,500 $\mathrm{kg} \mathrm{h}^{-1}$, respectively (Figure 3).

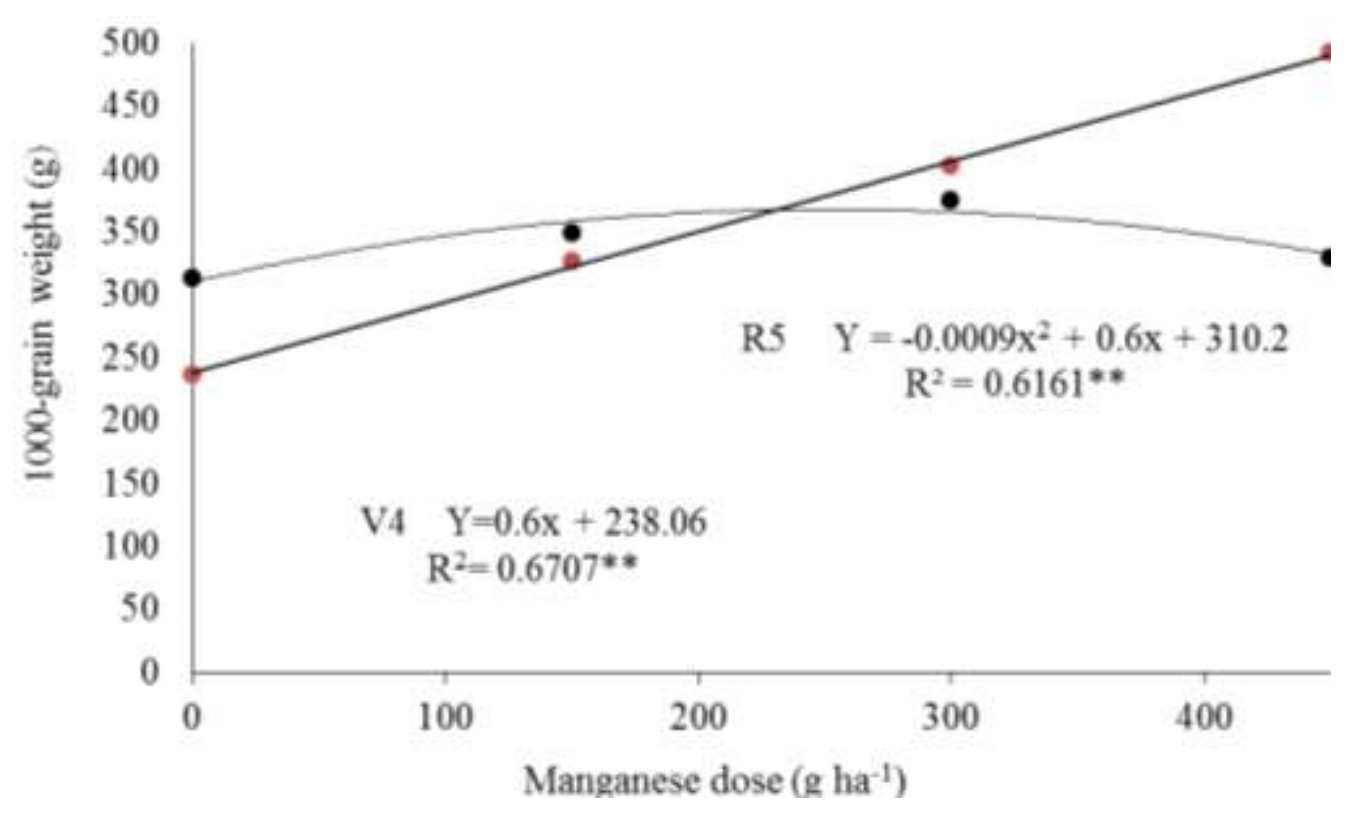

Figure 2. 1000-grain weight (g) according to the manganese doses applied in two periods on an irrigated common bean crop.

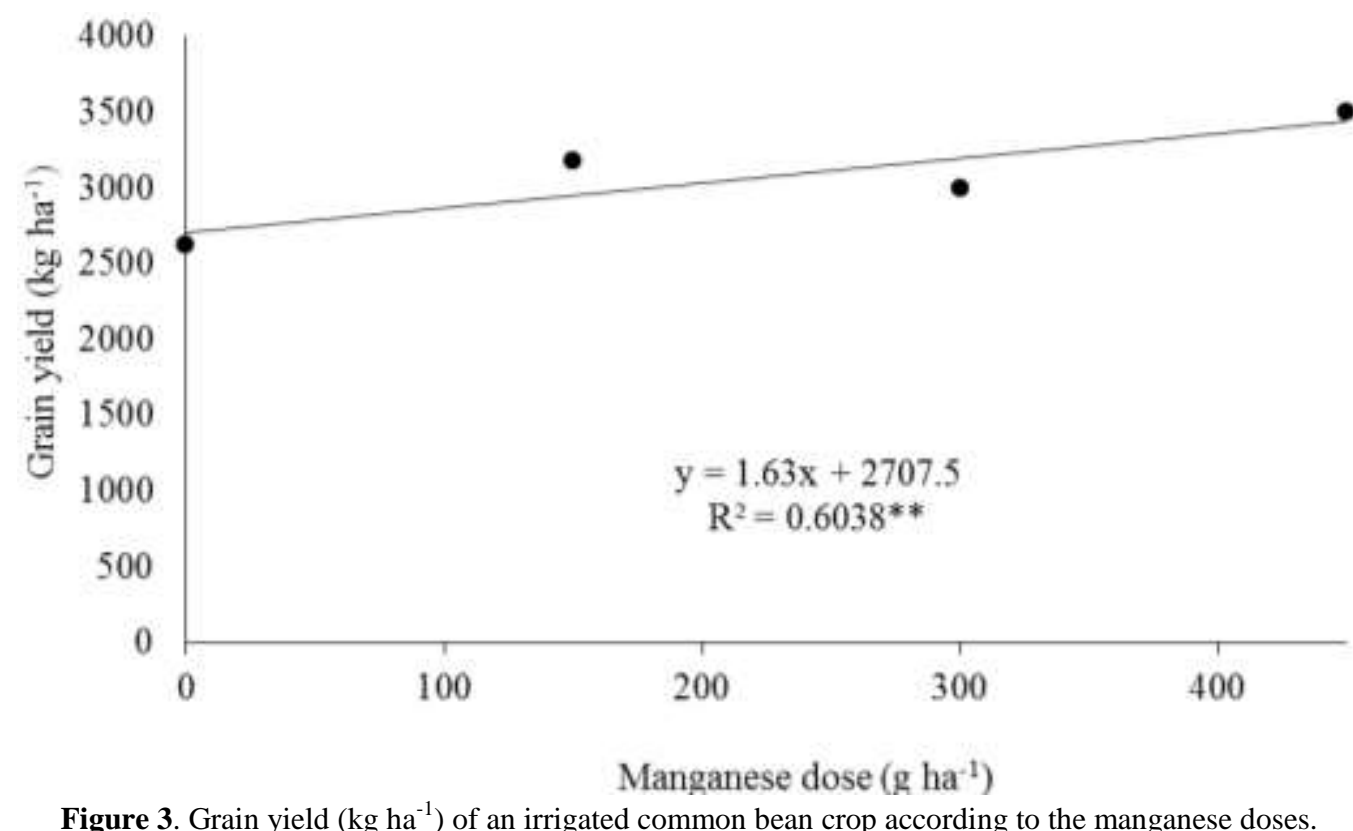


The grain yield $\left(\mathrm{kg} \mathrm{ha}^{-1}\right)$ increased according to the Mn doses (Figure 3). Teixeira et al. (2004) observed a grain yield of $2275 \mathrm{~kg} \mathrm{ha}^{-1}$ with the dose of $318 \mathrm{~g} \mathrm{ha}^{-1}$ of Mn with fertilization associated with $280 \mathrm{~g} \mathrm{ha}^{-1}$ of zinc. In soybean crops, the manganese used in different ways promotes higher yields (Mann et al., 2011). Carvalho et al. (2015), working with Mn doses (0, 200, 400, and 600 $\left.\mathrm{g} \mathrm{ha}^{-1}\right)$ in a soybean crop, observed that the application in $\mathrm{R} 1$ occurred provided higher yield than in R3. Thus, the authors state that applying doses close to $150 \mathrm{~g} \mathrm{ha}^{-1}$ of $\mathrm{Mn}$ has better effects in the increments of soybean yield.

\section{Conclusions}

The dose of $450 \mathrm{~g} \mathrm{ha}^{-1}$ of manganese provides the highest yield regardless of the application period. The highest number of pods per plant is obtained with the dose of $150 \mathrm{~g} \mathrm{ha}^{-1}$ applied in V4.Applied in stage V4, the dose of $450 \mathrm{~g} \mathrm{ha}^{-1}$ of manganese provides the highest 1000 -grain weight.

The definition of yield and 1000-grain weight occurs in stage V4. These parameters are already defined in R5, and the applied nutrient does not provide any increase.

\section{Authors' Contribution}

Mateus Gonçalves Rodrigues contributed to the implatition of experiment, data collection, irrigation and writing the manuscript. Eliene Wellita Vieira Barcelos Ramos contributed to writing, interpretation of results and revision of the manuscript writing and Wilian Henrique Diniz Buso contributed to writing, statistical analysis, interpretation of results and final correction of the manuscript.

\section{Bibliographic References}

Bueno, A.L., Czepielewski, M.A. 2007. Micronutrientes envolvidos no crescimento. Revista HCPA, Porto Alegre, 27(3), 47-56.

Carvalho, E.R., Oliveira, J.A., Costa Neto, J., Silva, C.A.T., Ferreira, V.F. 2015. Doses e épocas de aplicação de manganês via foliar no cultivo de soja convencional e em derivada transgênica RR. Bioscinse Journal. Uberlândia, 31(2), 252-361.

CONAB. COMPANHIA NACIONAL DE ABASTECIMENTO. 2019. Ministério da Agricultura, Pecuária e Abastecimento. 100 p. Perspectivas para a agropecuária, SAFRA 2019/20 - N. 7. Brasília, Ministério da Agricultura, Pecuária e Abastecimento. https://www.conab.gov.br/perspectivas-para-a-agropecuaria. (acessado 22 de setembro de 2019).

CONAB. COMPANHIA NACIONAL DE ABASTECIMENTO. 2020. Ministério da Agricultura, Pecuária e Abastecimento. Acompanhamento de Safra Brasileira, SAFRA 2020/21 - N. 8 - Primeiro levantamento. Brasília, Ministério da Agricultura, Pecuária e Abastecimento, 77 p. https://www.conab.gov.br/info-agro/safras/graos/boletim-dasafra-de-graos. (acessado em 22 de junho de 2021).
EMBRAPA. EMPRESA BRASILEIRA DE PESQUISA AGROPECUÁRIA. 2020. Trilha Tecnológica: Feijão. Embrapa Agrossilvipastorial, Sinop. https://www.embrapa.br/agrossilvipastoril/sitio-tecnologico/trilhatecnologica/tecnologias/culturas/feijao (acessado 27 de dezembro de 2020).

Fernandes, D.S., Soratto, R.P., Kulczynski, S.M., Biscaro, G.A., Reis, C.J. 2007. Produtividade e qualidade fisiológica de sementes de feijão em consequência da aplicação foliar de manganês. Pesquisa Agropecuária Brasileira, Brasília, 42(3), 419-426. https://doi.org/10.1590/S0100-204X2007000300016

Lacerda, E.G., Sanches, L.F.J., Queiroz, J.O., Silva, C.P. 2020. Adubação nitrogenada no vigor das mudas, concentração de aminoácidos e proteínas totais e no teor de clorofila no feijão-de-corda (Vigna unguiculata). Revista Agri-Environmental Sciences, Palmas, 6(e020002), 1-11. DOI: https://doi.org/10.36725/agries.v6i0.1413

Mann, E.N., Rezende, P.M., Carvalho, J.G., Corrêa, J.B.D. 2001. Efeito da adubação com manganês no rendimento e na qualidade de sementes de soja. Pesquisa Agropecuária Brasileira, Brasília, 37(12), 1757-1764. Disponível em: https://seer.sct.embrapa.br/index.php/pab/article/view/6528/35 85. (acessado 28 de outubro de 2020) .

Marschner, H. 2011. Mineral nutrition of higher plants, third ed. Academic Press, New York.

Mota, M.A., Machado Filho, G.C., Rocha, W.S., Silva, F.R., Santos, M.M. 2018. Efeito de doses de manganês no desenvolvimento do feijão-caupi. Tecnologia e Ciência

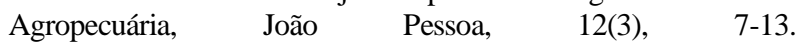
https://revistatca.pb.gov.br/edicoes/volume-12-2018/volume-12n-3-2018/02-ce-0318-09-efeito-de-doses-de-manganes-nodesenvolvimento-de-feijao-caupi.pdf. (acessado 28 de junho de 2021).

Nascente, A.S., Kluthcouski, J.,Crusciol, C.A.C., Cobucci, T., Oliveira, P. 2012. Adubação de cultivares de feijoeiro comum em várzeas tropicais. Pesquisa Agropecuária Tropical, 42, 407415. DOI: https://doi.org/10.1590/S1983-40632012000400003

Oliveira, M.G.C., Oliveira, L.F.C., Wendland, A., Guimarães, C.M., Quintela, E.D., Barbosa, F.R., Carvalho, M.C.S., Lobo Junior, M., Silveira, P.M. 2018. Conhecendo a Fenologia do Feijoeiro e Seus Aspectos Fitotécnicos. Embrapa Arroz e Feijão, Santo Antônio de Goiás, 59p. https://www.embrapa.br/buscade-publicacoes/-/publicacao/1085830/conhecendo-a-fenologiado-feijoeiro-e-seus-aspectos-fitotecnicos. (acessado 30 de novembro de 2019).

Oliveira, I.B., Mendonça, G.W., Binotti, F.F.S., Ascoli, A.A., Costa, E. 2015. Fertilizante foliar em feijoeiro de inverno e sua influência na produtividade e qualidade fisiológica das sementes. Revista de Agricultura Neotropical, Cassilândia, 2(2), 57-67. DOI: https://doi.org/10.32404/rean.v2i2

Slywitch, E. 2012. Guia alimentar de dietas vegetarianas para adultos. SVB, São Paulo.

Taiz, L., Zeiger, E. 2013. Fisiologia vegetal, fifth ed. Artmed, Porto Alegre.

Teixeira, I.R., Borém, A., Araújo, G.A.A., Fontes, R.L.F. 2004. Manganese and zinc leaf application on common bean grown on a "cerrado" soil. Scientia Agricola, Piracicaba, 61(1), 77-81. DOI: https://doi.org/10.1590/S0103-90162004000100013 